\title{
eemeraldinsight
}

\section{Management Decision}

Walking into the Room with IP: Exploring Start-ups' IP Licensing Strategy

Paola Belingheri, Maria Isabella Leone,

\section{Article information:}

To cite this document:

Paola Belingheri, Maria Isabella Leone, (2017) "Walking into the Room with IP: Exploring Start-ups' IP Licensing Strategy", Management Decision, Vol. 55 Issue: 6, doi: 10.1108/MD-04-2016-0227

Permanent link to this document:

http://dx.doi.org/10.1108/MD-04-2016-0227

Downloaded on: 05 J une 2017, At: 06:05 (PT)

References: this document contains references to 0 other documents.

To copy this document: permissions@emeraldinsight.com

Access to this document was granted through an Emerald subscription provided by emerald-srm:211360 []

\section{For Authors}

If you would like to write for this, or any other Emerald publication, then please use our Emerald for Authors service information about how to choose which publication to write for and submission guidelines are available for all. Please A visit www. emeral dinsight. com/ authors for more information.

\section{About Emerald www.emeraldinsight.com}

Emerald is a global publisher linking research and practice to the benefit of society. The company manages a portfolio of more than 290 journals and over 2,350 books and book series volumes, as well as providing an extensive range of online products and additional customer resources and services.

Emerald is both COUNTER 4 and TRANSFER compliant. The organization is a partner of the Committee on Publication Ethics (COPE) and also works with Portico and the LOCKSS initiative for digital archive preservation.

*Related content and download information correct at time of download. 


\title{
Walking into the Room with IP: Exploring Start-ups' IP Licensing Strategy
}

\begin{abstract}
Purpose: The paper explores trends and features of one of the most visible IP management practices, IP licensing, in the context of start-ups, accessing external technology at the outset of their lifetime. In particular, it compares start-ups and incumbent firms, in terms of licensing strategy pursued, role of in-licensed technologies relative to the internal innovation process and IP management strategies successively implemented.

Design/methodology/approach: A mixed-method study is presented using quantitative data on licensing deals from the USA SEC and cases on start-up companies involved in in-bound technology licensing.

Findings: Evidence indicates start-ups have different IP licensing strategies than incumbents and their successive IP management strategies are more flexible than for incumbents. Originality/value: We shed light on IP licensing, which is gaining momentum in open innovation settings, in an under-studied segment of SMEs, namely start-ups. We display interesting evidence of the portion of start-ups that license-in from external companies, indicating that this practice is more widespread than literature would suggest; we demonstrate that licensing-in is a valuable strategy for start-up companies, possibly providing additional channels for acquiring know-how on the market. We therefore contribute to, and advance, entrepreneurship, IP and Open Innovation literature.
\end{abstract}

"Certainly to be able to walk into the room with IP $[\ldots]$ that is an advantage",1

\section{Introduction}

Intellectual Property (IP) management has gained a central role in the modern competitive environment, where firms are increasingly considering the use of Open Innovation (OI) strategies (Chesbrough, 2003), in the attempt to successfully bring novel products and services to market. In this new innovation model, IP is no longer considered a consequence of R\&D efforts, but rather a key element in the innovative process, not only ensuring appropriability, but also providing access to markets, partners and valuable knowledge (Chesbrough, 2006; Chesbrough et al., 2014).

Recent literature has provided evidence of and a theoretical underpinning for the interplay between IP in OI settings for different firm categories (Chesbrough, 2006; Chesbrough et al., 2014). Several works have unveiled large companies' (e.g. Dodgson et al., 2006; Mortara and Minshall, 2011; Somaya, 2012.) and incumbents' attitudes (i.e. Frankenberger et al., 2014); a few authors have showed that Small and Medium Enterprises (SMEs), which are participating in OI processes at an unprecedented rate, usually pursue different practices to those of their larger counterparts (Van De Vrande et al., 2009; Spithoven et al., 2013). Given their liability of smallness, they appear as the best candidates to implement boundary-spanning practices (Chesbrough et al., 2014), being less inclined towards formal protection mechanisms (Lanjouw and Schankerman, 2004; Arundel, 2001; Leiponen and Byma, 2009). To the best of our knowledge, with the exception of a few, mostly anecdotic, studies, (e.g. Chesbrough, 2006; Gans et al., 2002; Eftekhari and Bogers, 2015), the start-up company subset of SMEs has been almost unexplored, although they have become increasingly active in open innovation settings (Neyens et al., 2010; West and Bogers, 2016). In their case, not only the liability of smallness but also the liability of newness (Bruderl and Schussler, 1990) may pose challenges in the execution of OI practices, in terms of appropriability and exchange.

\footnotetext{
${ }^{1}$ Interview with an entrepreneur licensing-in technology conducted in 2014.
}

\section{Page 1 of 18}


Among the main mechanisms for IP management, IP licensing is one of the most frequently used ones. It establishes a fruitful connection to the innovation process (Leone et al., 2016; Leone and Reichstein, 2012; Chesbrough, 2006) and it is increasingly recognized as a mechanism for managing in-bound and out-bound knowledge flows within collaborative arrangements (Chesbrough et al., 2014). Moreover, IP Licensing is also increasingly recognized as a tool to promote the creation of new businesses (WIPO, $2015^{2}$ ), built around the licensed technology.

Inspired by these new trends, we aim to identify which IP licensing strategy is adopted by start-ups accessing external technology in their in-bound open innovation processes, comparing them to incumbent firms, in order to evaluate key similarities and differences. More in detail, we examine which type of IP is acquired in terms of the relative distance to the acquiring firm's knowledge base, as well as which type of IP management strategies are subsequently pursued in terms of further technology trajectories and appropriation strategies. Attempting a new perspective within a relatively well-studied field, we chose an exploratory study, based on a mixed research methodology (Edmondson and McManus, 2007), setting the stage for further research.

We contribute to emerging research on IP management in OI settings, which has focused mainly on large and incumbent firms (Somaya, 2012; Dodgson et al., 2006; Mortara and Minshall, 2011; Frankenberger et al., 2014). We enhance the debate by focusing on start-ups (as encouraged by West and Bogers, 2016), an under-explored subset of SMEs. As the technology being accessed is patented, the start-ups in question will, in the authors' view, have a greater incentive to develop IP management policies, while reflecting on how to build around the patents they have acquired. IP inlicensing is therefore an ideal setting in order to contribute to entrepreneurship, IP management and OI literature.

In the remainder of the paper, Section 2 introduces the literature on OI and IP management, followed by IP licensing, by bringing to the surface the start-ups' perspective, as compared to incumbent's behavior. Section 3 describes the study, the dataset, the methodology and the findings. Section 4 concludes and proposes further research.

\section{Literature Review}

\subsection{Start-ups' IP Management in OI settings}

As all types of firms are increasingly opening their boundaries to source knowledge, crafting and executing an IP management strategy becomes fundamental to reap the benefits of openness (Teece, 1986; Chesbrough, 2003; Van De Vrande et al., 2009; Chesbrough, 2016).

IP Management has usually been studied in the context of large firms, which typically own huge R\&D portfolios (Somaya, 2012), however, several benefits may also accrue to start-ups. For instance, patents grant the owners freedom to operate on the market, protecting firms from economically constraining litigation actions, especially against large and established counterparts. IP also provides signaling towards venture capital investors, whose equity capital may be essential for growth (Conti et al., 2013; Gans and Stern, 2003). Moreover, IP can enhance the firm's value in the eyes of partners and customers, which may favorably appraise the firm's technological capability in the absence of performance metrics (Brant and Lohse, 2013). Definitively, using IP assets strategically can improve the efficiency with which start-ups' intellectual capital is exploited (Quinn et al., 1996) and therefore substantially affects their overall competitiveness, which is crucial for growth and survival. Accordingly, Helmers and Rogers (2011) found that patenting startups experience higher asset growth rates and better survival rates both in medium and high-tech sectors. However, despite these proven advantages, only a small percentage of start-ups actually take advantage of a proactive IP management strategy, as only few patent their IP (Helmers \& Rogers, 2011; Graham and Sichelman, 2008), mainly due to the cost of obtaining and defending patents and the possibility of disclosing information that competitors could patent-around (Graham et al., 2009). Indeed especially smaller firms seem to value secrecy over patenting (Arundel, 2001)

\footnotetext{
${ }^{2}$ http://www.wipo.int/sme/en/ip business/licensing/licensing.htm, accessed December 2015.
}

\section{Page 2 of 18}


with the exception of those in industries where reverse-engineering is common practice (Moser, 2012).

In the current scenario, characterized by blurred organizational boundaries and intense interfirm relationships, engaging in IP management can disclose additional advantages to companies. IP may not only be a means for appropriation but also a facilitator of knowledge exchange, and therefore a prerequisite for partnering (Chesbrough et al., 2014). This is particularly true for startups, where IP, when available, represents one of the few valuable assets they possess (Chesbrough et al., 2014; Brant and Lohse, 2013). Start-ups may have in fact greater difficulties in commercializing their technology effectively as they lack capabilities and contacts in their market. They may therefore compensate with a more learning-oriented approach (Parnell et al., 2015), using patents as an essential tool to access partners and to ensure appropriability of the collaboration outcome.

\subsection{Start-ups' IP Licensing}

\subsubsection{Start-ups' IP Licensing Trends}

Licensing is increasingly adopted in OI settings, as it is one of the most recognized and frequently used methods to exchange IP, in the form of patents (Arora and Ceccagnoli, 2006; Arora and Fosfuri, 2003; Chesbrough, 2003). It enhances the possibility to collaborate among innovation stakeholders (Chesbrough, 2003; 2006; WIPO, 2015), and in general increases the spread of ideas and innovation in the economic system.

The supply and demand for technology licenses can come from firms already operating on the market (e.g. Gans and Stern, 2002; Ceccagnoli and Jiang, 2013) and more recently also from start-ups. The 2008 Berkeley Patent Survey, for instance, revealed that $15 \%$ of the start-ups reported licensing-in technology, as another channel of learning from external actors (Graham et al. 2009). Prior literature has mainly focused on licensor start-ups that may want to commercialize their knowledge by licensing-out to incumbent firms (e.g. Gans et al., 2002; Kessel and Hall, 2006). However, there are various reasons why start-ups are also good candidates for licensing-in. Patents held by other firms can act as obstacles that start-ups must deal with, as they may need an external technology to bring a product idea to life, thereby avoiding litigation, which could be particularly detrimental for more resource-constrained firms. However, the same survey evidence (Graham et al., 2009) demonstrated that only $20 \%$ of startups mentioned the litigation motivation, and most preponderantly after raising large amounts of venture capital or launching an Initial Public Offering (IPO). On the contrary, the remaining start-ups declared that they licensed-in to "gain technology, information or know-how" from other players. This seems to indicate that budding, resourceconstrained startups are in-licensing external IP mainly to learn.

\subsubsection{Start-ups' IP In-licensing Strategy}

Being newcomers on the market, start-ups suffer from the liability of newness/adolescence, which depends on both their age and their initial resource endowments (Bruderl and Schussler, 1990). The more resources a start-up employs, the later it comes to face failure pressures on the marketplace; therefore, initial resource endowments are critical for success (Fichman and Levinthal, 1991).

Licensing-in technology can add to a start-up's resource base, however it can be costly both in terms of contractual negotiations, fees and royalties, and also in terms of the potential buyers' cost of integrating external technologies (Laursen et al., 2010; Ceccagnoli and Jiang, 2013), and this depends on the exploitative vs explorative nature of external technology acquisition. The level of so-called Absorptive Capacity (Cohen and Levinthal, 1990), indeed depends on how close the exchanged knowledge is to the receiving firms' knowledge pool (Ceccagnoli et al., 2014, Yang and Steensma, 2014). Accordingly, Tsai and Wang (2007) have shown that the effect of licensing-in on firm performance is positively moderated by the firm's previous R\&D efforts, and therefore smaller firms have greater difficulties in learning from formal agreements with external partners (Almeida et al., 2003). In addition, a startup's ability to integrate external knowledge is also influenced by the 
founding team's knowledge, which may be either of a specific market need or of a specific technological innovation (Di Stefano et al., 2012). Finally, as license agreements involve the exchange of tacit knowledge, the relative distance of the licensing parties' knowledge base may also play a role and this explain why incumbent firms mostly conclude licensing agreements with competitors (i.e. firms operating in the same main SIC Code) (Kim and Vonortas, 2006). However, for start-ups, competing directly with incumbents in their main areas of expertise may not be a viable option, and they may pursue more explorative avenues through licensing (Laursen et al., 2010).

Licensing-in technology can also played a relevant role in the product/service of the firm and the ensuing benefits this can bring (Somaya, 2012; Nagarajan and Mitchell, 1998). For incumbents, technologies, which are in a firm's core technology fields, are considered strategic and the most likely to form the backbone of the firms' future competitive advantage. For this reason, they will be the main candidates for appropriation strategies (Teece et al., 1997). Similarly, for start-ups, which are in the process of acquiring and defining their assets and competencies (Brush et al., 2001), IP in their core technology fields may constitute the foundation of the companies' product family and would seem the obvious choice when licensing-in. However, in case start-ups license-in to learn (Graham et al., 2009), implying they do not have the resources to compete with incumbents on proven technology, they may also consider licensing-in technologies that are complementary to their own knowledge base, in order to outperform competitors through novel combinations of existing technologies.

\section{Exploratory Analysis}

Our paper explores the IP licensing practices of start-ups by examining their characteristics and behaviors, compared to their incumbent competitors. Due to the nature of the research and the new perspective, we produce an intermediate study (Edmondson and McManus, 2007), combining quantitative and qualitative data. In particular, the quantitative analysis provided overall statistics on the phenomenon, and shed light on the similarities and differences in terms of licensing strategy, the exchanged knowledge and the subsequent IP management strategies. However, the quantitative analysis was unable to inform important aspects identified during the theoretical review. Therefore, our complementary qualitative analysis deepened the understanding of the start-ups' initial knowledge motivating the licensing strategy and the technology's role (core vs non-core) relative to the internal knowledge base.

\subsection{Quantitative Analysis}

The dataset consists of licensing agreements concluded between 1976 and 2013, compiled by KTMine ${ }^{3}$. Data sources include publicly available databases, primarily US Securities and Exchange Commission (SEC) documents ${ }^{4}$. All the agreements from 1980 to 2010 were extracted, allowing for minimum 5 years of additional patenting data for the most recent licensing contracts. From these 7676 agreements, all participants were matched with Orbis, giving a total of 890 matched licensors and 462 matched licensees with data on their primary SIC codes, incorporation date, country and all their granted patents until the $31^{\text {st }}$ of December 2015. Only the agreements with complete data for both licensor and licensee were considered, leading to a representative subsample of 752 agreements. For each agreement we took all the licensor and licensee pairs, and using patent data we calculated their main patenting class(es) before and after the licensing deals.

In order to differentiate between start-ups and incumbents conservatively, since no objective economic criteria can be defined, we based the distinction on firm age. As licensing agreements can

\footnotetext{
${ }^{3}$ See www.ktmine.com., retrieved June 2015.

${ }^{4}$ Public corporations disclose to the SEC (EDGAR) all activities that could affect their balance sheet. Since patents are assets, licensing agreements should be reported to the SEC through the 8-K form that companies are only required to file when a "material event" takes place. It is also widely known that companies prefer to keep licensing information confidential when possible. Therefore this database contains a sampling bias.
} 
take up to a year to be defined (e.g. The Stanford Office of Technology Licensing Guide ${ }^{5}$ ), we decided to select those licensees that received the license within the first two years from their incorporation date. We identified $13.6 \%$ of records with start-up licensees and $86.4 \%$ of records with incumbent licensees. We used t-tests to evaluate differences between start-ups and incumbents (see Appendix 1 for the T-test results).

\subsubsection{Start-ups' IP In-licensing Statistics}

In order to confirm the importance of the phenomenon, Figure 1 shows that licensing to start-ups is indeed occurring consistently over the sampling period, reinforcing the interest for further research. Start-ups average age at licensing is 8 months, whereas incumbents are on average 23.3 years old.

Figure-1 - Number of Start-up (1) and Incumbent (0) Licensees Entering Licensing Agreements

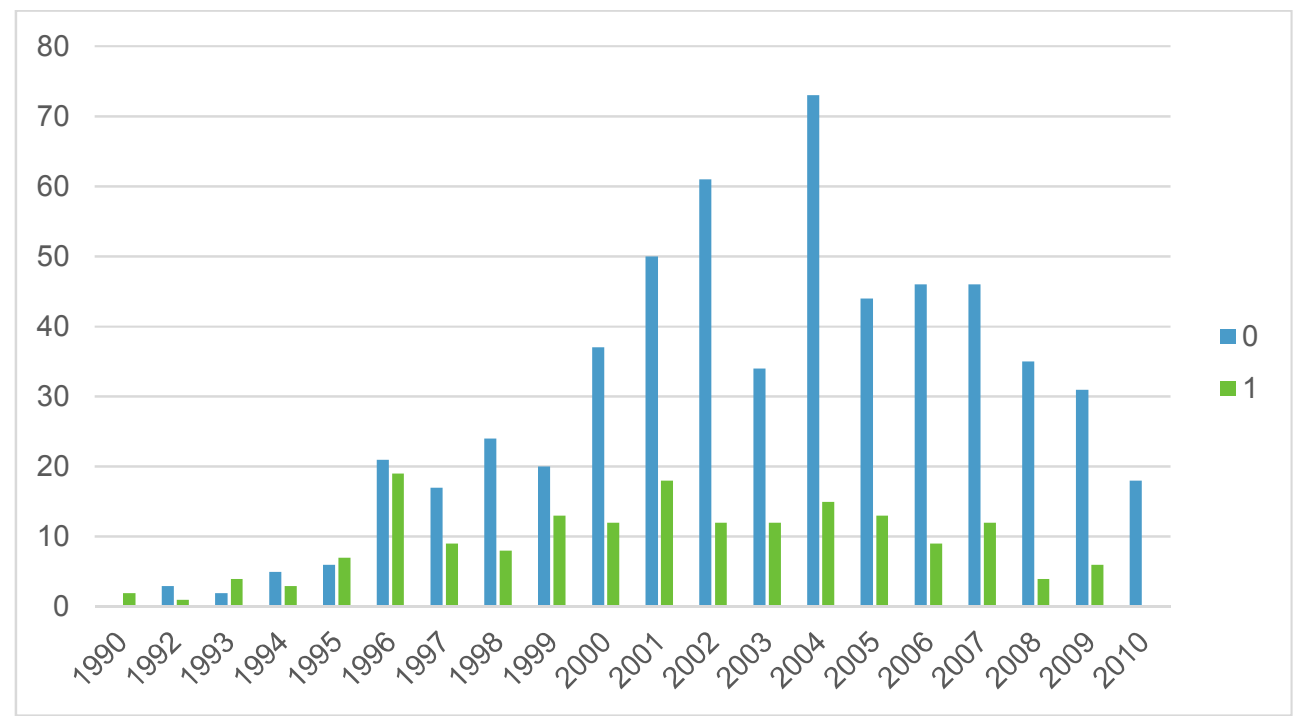

Examining the geographical distribution of the deals, participating licensees ae distributed in 21 countries with the majority in the USA, Europe (Top 5: Germany, Great Britain, France, Ireland, Switzerland), Canada and Japan. Start-ups are mainly concentrated in the USA and Europe (France and Germany), These countries also present the highest number of deals overall, which may indicate that licensing out to start-ups is only undertaken in significantly developed technology markets, where participating firms have a solid licensing experience (Table 1).

InsertTable1AboutHere

The agreements are spread out over many SIC codes, both in manufacturing and services. This is also the case for start-ups, which are present mainly in manufacturing-intensive sectors such as Chemistry and Mechanics and to a lesser degree in Telecommunications, Software and Other Services (Van De Vrande et al., 2009).

InsertTable2AboutHere

We find that $93 \%$ of all licenses to start-ups come from private firms, suggesting that startups are embracing a complementary approach to the traditional university/research center spin-off model (Perkmann et al., 2013). A more detailed analysis per licensor type shows that $33 \%$ of private firms' licenses go towards start-ups, and similarly $35 \%$ of university licenses go to start-ups.

\footnotetext{
${ }^{5}$ http://otl.stanford.edu/documents/OTLStart-Upguide.pdf, accessed September 2015.
}

\section{Page 5 of 18}


This is in line with growing evidence of diffusion of inside-out OI practices carried out by established firms that seek to "identify new adjacencies and business opportunities around their core businesses" (Chesbrough et al., 2014, Chesbrough and Socolof, 2000).

\section{InsertTable3AboutHere}

\subsubsection{Start-ups' IP In-licensing Strategy}

\subsubsection{Types of Licensing Deals and Licensed Technologies}

Start-ups could have different motivations than incumbents to license-in. Participation in cross-licensing, where both parties exchange technology to ensure reciprocal freedom to operate, versus one-way licensing, may illustrate this difference. Indeed in our sample start-ups are significantly less likely to participate in cross-licensing deals than incumbents, indicating that for them licensing is less likely to be a litigation avoidance measure (Graham et al. 2009).

\section{InsertTable4AboutHere}

Regarding exploitation vs exploration, we look for different licensing patterns depending on whether the SIC code, traditionally used to classify the underlying knowledge, of the partners or the licensed technology overlaps ${ }^{6}$. We therefore distinguish the following five scenarios, which present different degrees of exploration and exploitation:

1) Licensor, licensee and technology all share the same main SIC code

2) Licensee and technology have the same main SIC code, but differ from the licensor's

3) Licensor and licensee have the same main SIC code, but differ from the technology

4) Licensor and technology have the same main SIC code, but differ from the licensee's

5) Licensor, licensee and technology all have different main SIC codes.

We find that incumbents are significantly more likely to operate in scenario 1 through 4 , whereas start-ups are more significantly operating in scenario 5 . This evidence suggests that startups are less likely to license-in technologies from direct competitors and with an immediate application in their core market, than incumbent firms. This may indicate that indeed startups are learning from technologies complementary to their current knowledge base and are performing more exploration than exploitation. They are therefore using licensing as an explorative instrument (Laursen et al., 2010).

\subsubsection{IP Management Strategies Following the License}

After the initial licensing deal, 55 start-ups also licensed-in further technology, whereas the remaining 58 had no further licensing activities by 2010. So roughly half of the companies, attempt to find alternative IP development or sourcing strategies, whereas the remaining firms decide to further acquire technologies on the market.

As expected, incumbents have significantly higher patent stocks than start-ups and the same holds for the patent scope (number of distinct patent technological classes) which is broader in the case of incumbents. Firms are more likely to narrow their patent scope after licensing-in, focusing their R\&D efforts around the field of the in-bound technology (Leone and Reichstein, 2012) and we see this effect for both start-ups and incumbents.

As a complementary analysis, we examined the firms' main patenting classes before and after each licensing deal. Start-ups are significantly less likely to maintain their main technological class after the agreement, indicating that additional patenting activities following the initial deal are not necessarily remaining in the same technology field, rather they are moving away from the

\footnotetext{
${ }^{6}$ For the firms we used the main SIC Codes as reported in Orbis, whereas for the license we used the SIC Code for the agreement as reported in the KTMine Database
}

Page 6 of 18 
technology fields they were patenting in when they received the license. Therefore, instead of specializing, as incumbents tend to do, they are expanding their R\&D portfolio.

InsertTable7AboutHere

\subsection{Qualitative Analysis}

In order to have a more fine-grained investigation of the phenomenon, nine cases of startups that were born with an externally licensed technology, complemented the exploratory analysis (Table 8).

For each firm the founders/CEOs were interviewed, as well as key licensor's staff and external investors. A standard questionnaire, concentrating on the licensing process and its consequences for the start-up (Appendix 2), was elaborated in order to enable the comparison of results across interviews. Each interview lasted 30-60 minutes, and was conducted either in person or through videoconference. They were recorded, transcribed and complemented with press articles and company websites.

The coding was performed independently by the two authors following Weston et al. (2001), defining a coding manual at the outset, based on theoretical constructs to be examined, which was refined as the coding proceeded. Starting from the constructs that emerged from the theory, and while considering each firm as its own story, we aggregated the data and identified patterns between licensees.

\subsubsection{Start-up's IP in-Licensing Cases}

All interviewed companies were recently founded: in 2013 (3), in 2012 (4), in 2011 (1) and in 2009 (1). Consistently with the quantitative analysis, all start-ups licensed-in a technology within the first two years of their lifetime.

Examining the geographical coverage, the start-ups are founded in Europe (UK, Switzerland, The Netherlands, and Italy) and in the US, and operate in different sectors, which mirrors the quantitative dataset.

By design, we chose only two licensing institutions in order to decrease variability in licensing practices, since the quantitative data already had a high variability in terms of different licensors, however both were keen to license-out to start-up companies.

InsertTable8AboutHere-

\subsubsection{Start-ups' IP In-licensing Strategy}

\subsection{Types of Licensing Deals and Licensed Technologies}

Start-ups' main rationale for licensing-in is reported as either it being mandatory in order to bring a product or service to market, or as a resource for the firm to exploit in gaining competitive advantage. Among the main benefits cited, raising capital and signaling are mentioned by almost every start-up: "the license is important because for raising money for example everyone asks you "do you have the license, the license is $O K$ ?" and indeed one venture capitalist comments "IP is IP, obviously there's a respect for that". Consistently with the quantitative evidence, two mentioned mentions licensing-in "to ensure reciprocal freedom to operate".

Regarding the start-ups' Absorptive Capacity, some licensing deals occur starting from the licensees' in-depth knowledge of a market need, which drove the technology acquisition: "very much we knew what the market was, the market was crying out for a solution". In this case, the further knowledge needed by the managers concerns the suitability of the technology for the application: "We performed a 15 month feasibility study [...] and afterwards we knew what it [the technology, Ed.] could do for us" and also in-depth knowledge of the technology itself "I was employing the man who was the lead scientist on the initial development of the technology [...] he 
was the one who was doing the research for me". However, also the opposite case occurs, where the start-ups' founders have prior knowledge of the technology and seek to match this with an ideal market: "I looked at this [technology, Ed.] and I immediately made the connection that it might be an opportunity to [perform a certain task, Ed.] in certain situations. I didn't know much about it [the market, Ed.] but this was my first clue". In this case, the licensee not only needs to prove that the technology is suitable for a particular need through feasibility studies, but must also correctly identify the market and confirm the need is effectively there: "we invested more than 1M€ by now [...] doing a lot of market research and also market preparation. We talked with I think over 150 companies by now, we visited several trade shows in the world, [...] just to warm up the market, to see where the potential is and who our prospect customers would be."

The licensed technology also has different roles in the start-ups' products or services. In six out of nine start-ups the technology is at the core of their product/service offering and without it the advantages of the product w.r.t the competition would be nonexistent: "It's key, it's key [...] in this case there's no other technology that is capable of doing it [...] our product really depends on this licensed technology" and "We need that [license, Ed.] to be able to do what we're doing and we have to use that throughout the product". Three companies have, instead, a more complementary role for the licensed technology: "The product can be brought to market without the license, however this technology enables us to adapt our product to be used with many different battery models so we don't need to fix this issue early on in the engineering phase [...] we can negotiate with different suppliers without depending on any one of them". However, as expected from the previous analysis, this role of the licensed technology is not perceived as static by the start-ups but also has a dynamic connotation, changing in importance over time depending on the amount of further adaptation that is needed to bring the technology to the market, and on the overall complexity of the technology: "it's key but it's not all the only part because our technology is very complex so we patented other aspects of the technology so we have a broad portfolio of patents right now so as you can imagine the first patent of course is important but it's diluted by other patents". So over time the weight and the strategic importance of the licensed patent may be diluted out by additional R\&D efforts of the start-up. Therefore, the fact that a patent is a core part of a product/service when the licensing deal was made, doesn't guarantee that this will still be the case once the product gets to market. This ties in with the quantitative data which shows how Start-ups often change their main technology class in which they registered patents following the licensing deal.

\subsection{IP Management Strategies Following the License}

The interviews also shed light on the very different patenting strategies that firms put in place after receiving the license. As expected, the companies licensing-in complementary technology don't report further patenting activities as a result of the licensing deal. Instead, out of our sample of six companies that report acquiring the IP as a core element of their product/service, one reports using the licensed patent as a basis to build a patent pool, two applied for additional patents to protect their further R\&D activities, and, more counter-intuitively, two are keeping further patenting on-hold to evaluate costs versus benefits and one has decided not to use the original patent at all. This shows that, in contrast to extant literature that would expect strong appropriation strategies for core technologies within firms (Somaya, 2012), for these start-ups, the in-licensed IP can be seen as a dynamic tool, not only giving them specific knowledge or rights, but also conducive to different strategies such as secrecy or as a tool to gain additional benefits such as market penetration or access to funding.

\section{Conclusions and Further Research}

Our exploratory study provides evidence on IP licensing, which is one of the most frequently employed OI practices, instrumental for IP exchange (Arora and Ceccagnoli, 2006; Arora and Fosfuri, 2003; Chesbrough, 2003), in an under-studied segment of SMEs, namely startups. It therefore contributes to the recently explored SMEs compartment, both in the literature on 
OI (West and Bogers, 2016; Spithoven et al., 2013; Van De Vrande et al., 2009) and IP (Graham et al., 2009, Brant and Lohse, 2013).

Our findings overall display novel and interesting evidence of the portion of start-ups that license-in from external companies, indicating that this practice is as widespread as previous literature would suggest (Graham et al., 2009) and that licensing-in is a valuable strategy for startup companies, possibly providing additional channels for acquiring know-how on the market (Almeida et al., 2003), which still leave them flexibility to adapt their technology and pursue competitive advantage. More in detail, the study suggests that start-ups pursue different IP management strategies than incumbents when accessing external technologies through licensing, such as more exploration than exploitation-oriented strategies (Laursen et al., 2010) and less crosslicensing deals than simple technology acquisitions (Graham et al., 2009), executing more sophisticated IP management activities than suspected. They license-in not only core technologies (Teece et al., 1997, Brush, 2001), which may be fundamental to operate on the market, but also more complementary technologies that support their business strategy. Even more relevant and counterintuitive is that they do not necessarily rely on the in-licensed IP nor on the licensor's knowledge base (Spithoven et al., 2011) for nurturing their future innovation activities, using their further R\&D to dilute the dependency on the in-licensed technology, or still using secrecy to protect their further developments.

Following from these findings, a relevant managerial implication can be that technology searches by start-ups should not only be limited to identifying potential patent infringements (Graham et al., 2009) but should also consider technologies worth licensing-in, to acquire additional knowledge and to signal the use of IP without necessarily patenting their in-house technology. Patent holders and technology providers should also consider start-ups as potential technology acquirers alongside the more traditional incumbent firms on the market. Likewise, interesting research avenues include the study of IP trajectories following licensing deals towards start-ups, considering patents, their technology classes and their citations, in order to identify which aspects of the deals and licensed patents are conducive to different successive IP management. Moreover, as emerging research has highlighted how technology providers could learn from their technology recipients' further technology developments (Yang and Steensma, 2014), it would be interesting to examine how these technology trajectories travel down previously unexplored knowledge paths and how this could benefit licensors. Finally, adding a performance dimension to future research would enable to shed light on the extent to which engaging in licensing is more beneficial to start-ups than alternative IP strategies.

Finally, the paper contains some clear limitations. First of all, firms are not inclined to disclose licensing agreements, therefore the information present in public databases only covers part of the phenomenon and cannot represent the full picture. Second, the analysis suffers from a further limitation due to the difficulty to access non-patent data (e.g. financial and economic data) for startups that could have provided a more nuanced feedback on the effects of licensing-in for these firms. Third, the case-based evidence cannot be widely generalized as it is idiosyncratic to the two licensors' behavior and context; however it provides interesting insights informing future research. 


\section{Appendix 1 - T-Test Results}

Table 10 - T-Test Results

\begin{tabular}{|c|c|c|c|c|c|c|c|c|c|}
\hline \multirow{3}{*}{\multicolumn{2}{|c|}{ T-test for Variable }} & \multirow{3}{*}{$\begin{array}{l}\text { Correspondin } \\
\text { g Table }\end{array}$} & \multirow{3}{*}{$\begin{array}{c}\text { Incumbent } \\
\text { Mean }\end{array}$} & \multirow{3}{*}{$\begin{array}{l}\text { Start-up } \\
\text { Mean }\end{array}$} & \multicolumn{5}{|c|}{ Difference (Incumbent - Start-up) } \\
\hline & & & & & \multirow{2}{*}{ Mean } & \multirow{2}{*}{ Std. Err. } & \multicolumn{2}{|c|}{$95 \%$ Conf. Int. } & \multirow{2}{*}{$\begin{array}{l}\text { P-Values } \\
\operatorname{Pr}(|\mathrm{T}|>\mathrm{t} \mid)\end{array}$} \\
\hline & & & & & & & Lower & Upper & \\
\hline \multicolumn{2}{|c|}{ Cross-Licensing } & 4 & 0.0803438 & 0.0140258 & 0.314283 & 0.002399 & 0.026727 & 0.03613 & $<0.001$ \\
\hline \multirow{5}{*}{$\begin{array}{l}\text { Differences } \\
\text { between } \\
\text { Licensor, } \\
\text { Licensee } \\
\text { and } \\
\text { Technology } \\
\text { SIC Code }\end{array}$} & 1 & 5 & 0.009849 & 0.0053071 & 0.0045419 & 0.0020031 & .0006158 & .0084681 & 0.023 \\
\hline & 2 & 5 & 0.0514535 & 0.0272934 & 0.0241601 & 0.004482 & 0.015375 & .0329451 & $<0.001$ \\
\hline & 3 & 5 & 0.0311586 & 0.0291888 & 0.0019698 & 0.0036244 & -0.0051343 & 0.0090739 & 0.587 \\
\hline & 4 & 5 & 0.0332478 & 0.0140258 & 0.019222 & 0.0036071 & 0.0121518 & 0.0262922 & $<0.001$ \\
\hline & 5 & 5 & 0.8742912 & 0.924185 & -0.0498938 & 0.0067712 & -0.063166 & -0.0366216 & $<0.001$ \\
\hline \multicolumn{2}{|c|}{ Patent Stock } & - & 273.0365 & 64.48067 & 208.5559 & 33.54509 & 142.8046 & 274.3071 & $<0.001$ \\
\hline \multicolumn{2}{|c|}{ Patent Scope } & 6 & 19.12887 & 10.01403 & 9.114847 & 0.799581 & 7.547598 & 10.6821 & $<0.001$ \\
\hline \multicolumn{2}{|c|}{$\begin{array}{c}\text { Change in Patent } \\
\text { Scope }\end{array}$} & 6 & -8.630932 & $\begin{array}{c}- \\
0.5576194\end{array}$ & -8.07331 & 0.737246 & -9.51838 & -6.62825 & $<0.001$ \\
\hline \multicolumn{2}{|c|}{$\begin{array}{l}\text { Change in Main } \\
\text { Technology Class }\end{array}$} & 7 & 0.6411389 & 0.5155421 & 0.1255968 & 0.0101063 & 0.1057877 & 0.145406 & $<0.001$ \\
\hline
\end{tabular}

\section{Page 10 of 18}

(c) Emerald Publishing Limited

This is a pre-print of a paper and is subject to change before publication. This pre-print is made available with the understanding that it will not be reproduced or stored in a retrieval system without the permission of Emerald Publishing Limited. 


\section{Appendix 2 - Interview Questionnaire}

These interviews were part of a broader study into start-ups licensing-in technology. We only used responses to Q2-3, 5-9, 12 in this paper.

1) Describe your company, the key markets you operate in and your main product/service.

2) Describe the role the licensed technology plays in your final product/service.

3) Explain how you identified the technology available for licensing and at what stage this happened of your product/service development cycle.

4) What type of agreement do you have for the license?

5) How did you develop the licensed technology further once you acquired it?

6) Which are the key advantages you obtained by licensing-in this technology?

7) In what part were the advantages due to you being a start-up?

8) Which are the key issues you experienced by licensing-in this technology?

9) In what part were the issues due to you being a start-up?

10) Describe the relationship you had with the licensor and how this influenced your company.

11) Are there any other factors that influenced the success of the deal that you haven't mentioned so far?

12) Did you ever regret taking the license in the first place and why? 


\section{Appendix 3 - Sample Representativeness Check}

\section{1) Representativeness Check:}

We compare the original sample of 7676 records to the subsample of 752 agreements on key variables:

- Yearly distribution of agreements. Since Orbis draws from public databases and the stock market, there could be exogenous variables driving the availability of information between the different waves of innovation activity spanning the last decades. To account for this, we tested the representativeness of the sample splitting it into three decades. Overall the sample is representative; we see that as we come to companies participating in more recent licensing activities, the subsample becomes increasingly representative of the overall sample.

- Different sectors. We create dummy variables for the main SIC Codes present in the sample and found that only category 2834 is slightly over-represented in our subsample while all others have no significant differences.

- Service/product license. We also confirmed that the subsample is representative looking at whether product or service technologies are exchanged.

Based on this comparison, we can conclude that the subsample is representative of the overall sample.

Table 11 - Sample Representativeness

\begin{tabular}{|c|c|c|c|c|c|c|}
\hline \multirow[b]{3}{*}{ Variable } & \multicolumn{2}{|c|}{ Individual Samples } & \multicolumn{4}{|c|}{ Difference Between Samples (T-Test) } \\
\hline & \multirow{2}{*}{$\begin{array}{c}\text { Average } \\
\text { Overall Batch } \\
(7676 \\
\text { licenses })\end{array}$} & \multirow{2}{*}{$\begin{array}{c}\text { Average } \\
\text { Subsample } \\
(752 \\
\text { licenses })\end{array}$} & \multirow[b]{2}{*}{ Average } & \multirow[b]{2}{*}{$\begin{array}{c}\text { Std } \\
\text { Dev }\end{array}$} & \multicolumn{2}{|c|}{$95 \%$ Interval } \\
\hline & & & & & $\begin{array}{l}\text { Lower } \\
\text { Bound }\end{array}$ & $\begin{array}{l}\text { Upper } \\
\text { Bound }\end{array}$ \\
\hline Agreement Year 1980-1990 & 1987.26 & 1986.88 & -0.39 & 0.86 & -2.10 & 1.32 \\
\hline Agreement Year 1991-2000 & 1997.33 & 1997.46 & 0.13 & 0.15 & -0.16 & 0.42 \\
\hline Agreement Year 2001-2010 & 2004.65 & 2004.74 & 0.09 & 0.12 & -0.15 & 0.33 \\
\hline SIC Code 2834 & 0.1763 & 0.2407 & 0.0643 & .0156 & 0.0338 & 0.0949 \\
\hline SIC Code 2836 & 0.0667 & 0.0664 & -.0003 & .0100 & -0.0199 & 0.0194 \\
\hline Sic Code 7372 & 0.0657 & 0.0636 & -0.0021 & 0.0099 & -0.0216 & 0.0174 \\
\hline Sic Code 3841 & 0.0607 & 0.0484 & -0.0123 & 0.0095 & -0.0308 & 0.0063 \\
\hline Sic Code 7389 & 0.0474 & 0.0373 & -0.0100 & 0.0084 & -0.0265 & 0.0065 \\
\hline Product (0)/Service (1) & 0.0901 & 0.0982 & 0.0081 & 0.0112 & -0.0139 & 0.0300 \\
\hline
\end{tabular}

2) Additional analysis to exclude that start-ups may be under-represented in our sample due to an over-representation of active companies w.r.t inactive ones in Orbis:

We checked for differences in active an inactive firms, in 2016, among the incumbent or startup licensees in our subsample. This difference is not statistically significant (T-test $95 \%$ interval is between -0.0525451 and 0.029398). Therefore companies in Orbis do not seem to be biased in favor of active companies, if we compare between start-up and incumbent firms in the subsample.

\begin{tabular}{lrr|} 
Status & Incumbent & Startup \\
\hline Active & $91.73 \%$ & $92.89 \%$ \\
Inactive & $8.26 \%$ & $7.11 \%$ \\
\hline Grand Total & $\mathbf{1 0 0 . 0 0 \%}$ & $\mathbf{1 0 0 . 0 0 \%}$
\end{tabular}




\section{References}

Almeida, Paul, Gina Dokko, and Lori Rosenkopf. 2003. "Startup size and the mechanisms of external learning: increasing opportunity and decreasing ability?" Research Policv 32, no. 2 301315.

Arora, A. and Ceccagnoli, M., 2006. Patent protection, complementary assets, and firms' incentives for technology licensing. Management Science, 52(2), pp.293-308.

Arora, A. and Fosfuri, A., 2003. Licensing the market for technology. Journal of Economic Behavior \& Organization, 52(2), pp.277-295.

Arundel, A., 2001. The relative effectiveness of patents and secrecy for appropriation. Research Policv, 30(4), pp.611-624.

Brant J., \& Lohse, S., 2013. "Enhancing intellectual property management and appropriation by innovative SMEs", ICC (International Chamber of Commerce) Innovation and Intellectual Property Research Paper.

Bruderl, J. and Schussler, R., 1990. Organizational mortality: The liabilities of newness and adolescence. Administrative Science Quarterly, pp.530-547.

Brush, C.G., Greene, P.G. and Hart, M.M., 2001. From initial idea to unique advantage: The entrepreneurial challenge of constructing a resource base. The academy of management executive, 15(1), pp.64-78.

Ceccagnoli, M., \& L. Jiang., 2013. The Cost of Integrating External Technologies: Supply and Demand Drivers of Value Creation in the Markets for Technology. Strategic Management Journal, Vol. 34, pp.404-425.

Chesbrough, H., 2003. The Logic of Open Innovation: Managing Intellectual Property. California Management Review, 45(3), pp.33-58.

Chesbrough, H., 2006. Open Innovation: the new imperative from creating and profiting from technology. Boston: Harvard Business School Press.

Chesbrough, H., 2016. Open Innovation: Researching a new paradigm. Oxford: Oxford Press.

Chesbrough, H. W. \& Socolof, S. J., 2000. Creating new ventures from Bell labs technologies. Research Technology Management, Volume 43, pp.13-17.

Chesbrough, H., Vanhaverbeke, W. \& West, J., 2014. New Frontiers in Open Innovation. s.1.:Oxford University Press.

Cohen, W.M. and Levinthal, D.A., 1990. Absorptive capacity: A new perspective on learning and innovation. Administrative science quarterly, pp.128-152.

Conti, A., Thursby, M. and Rothaermel, F.T., 2013. Show Me the Right Stuff: Signals for HighTech Startups. Journal of Economics \& Management Strategy, 22(2), pp.341-364. 
Di Stefano, G., Gambardella, A. \& Verona, G., 2012. Technology push and demand pull perspectives in innovation studies: Current findings and future research directions. Research Policv. 41(8), pp.1283-1295.

Dodgson, M., Gann, D. and Salter, A., 2006. The role of technology in the shift towards open innovation: the case of Procter \& Gamble. $R \& D$ Management, 36(3), pp.333-346.

Edmondson, A.C. and McManus, S.E., 2007. Methodological fit in management field research. Academy of management review, 32(4), pp.1246-1264.

Eftekhari, N., \& Bogers, M. 2015. Open for Entrepreneurship: How Open Innovation Can Foster New Venture Creation. Creativitv and Innovation Management, 24(4), 574-584.

Fichman, M. and Levinthal, D.A., 1991. Honeymoons and the liability of adolescence: A new perspective on duration dependence in social and organizational relationships. Academy of Management review, 16(2), pp.442-468.

Frankenberger, K., Weiblen, T. and Gassmann, O., 2014. The antecedents of open business models: an exploratory study of incumbent firms. R\&D Management, 44(2), pp.173-188.

Gans J. S., Hsu D. H., Stern S., 2002. When does Start-up innovation spur the gale of creative destruction? RAND Journal of Economics 33(4):571-586.

Gans, J.S. and Stern, S., 2003. The product market and the market for "ideas": commercialization strategies for technology entrepreneurs. Research nolick, 32(2), pp.333-350.

Graham, S. J., Merges, R. P., Samuelson, P., \& Sichelman, T. 2009. High technology entrepreneurs and the patent system: Results of the 2008 Berkeley patent survey. Berkeley Technology Law Journal:1255-1327.

Graham, S.J. and Sichelman, T., 2008. Why do start-ups patent? Berkeley Technology Law Journal, 23(3), pp.1063-1097.

Helmers, C. \& Rogers, M. 2011. Does patenting help high-tech start-ups? Research Policy, 40(7):1016-1027.

Kessel, M. \& Hall, S., 2006. Avoiding premature licensing. Nature Reviews Drug Discoverv, Volume 5, pp.985-986.

Kim, Y., and Vonortas N.S. 2006. "Technology licensing partners." Journal of Economics and Business 58, no. 4 (2006):273-289.

Lanjouw, J. O. \& Schankerman, M., 2004. Patent Quality and Research Productivity: Measuring Innovation with Multiple Indicators. The Economic Journal, 114(495), pp.441-465.

Laursen, K., Leone, M.I. and Torrisi, S., 2010. Technological exploration through licensing: new insights from the licensee's point of view. Industrial and Corporate Change, p.dtq034.

Leiponen, A. \& Byma, J., 2009. The relative effectiveness of patents and secrecy for appropriation. Research Policv, 38(9), pp.1478-1488.

Leone, M. I. \& Reichstein, T., 2012. Licensing-in fosters rapid invention! the effect of the grantback clause and technological unfamiliarity. Strategic Management Journal, 33(8), pp.965-985.

\section{Page 14 of 18}

(c) Emerald Publishing Limited

This is a pre-print of a paper and is subject to change before publication. This pre-print is made available with the understanding that it will not be reproduced or stored in a retrieval system without the permission of Emerald Publishing Limited. 
Leone, M. I., Reichstein, T., Boccardelli, P. and Magnusson, M. 2016. License to learn: an investigation into thin and thick licensing contracts. $\underline{R \& D \text { Management, }}$ 46:326-340.

Mortara, L. and Minshall, T., 2011. How do large multinational companies implement open innovation? Technovation, 31(10), pp.586-597.

Moser, P., 2012. Patent laws and innovation: evidence from economic history (No. w18631). National Bureau of Economic Research.

Nagarajan, A., \& Mitchell, W. (1998). Evolutionary diffusion: Internal and external methods used to acquire encompassing, complementary, and incremental technological changes in the lithotripsy industry. Strategic Management Journal, 1063-1077.

Neyens, I., Faems, D. and Sels, L., 2010. The impact of continuous and discontinuous alliance strategies on startup innovation performance. International Journal of Technologv Management, 52(3/4), pp.392-410.

Parnell, J.A., Long, Z. and Lester, D., 2015. Competitive strategy, capabilities and uncertainty in small and medium sized enterprises (SMEs) in China and the United States. Management Decision, 53(2), pp.402-431.

Perkmann, M., Tartari, V., McKelvey, M., Autio, E., Broström, A., D’Este, P., Fini, R., Geuna, A., Grimaldi, R., Hughes, A. and Krabel, S., 2013. Academic engagement and commercialisation: A review of the literature on university-industry relations. Research Polick, 42(2), pp.423-442.

Quinn, J.B., Anderson, P. and Finkelstein, S., 1996. Leveraging intellect. The Academy of Management Executive, 10(3), pp.7-27.

Somaya, D., 2012. Patent strategy and management an integrative review and research agenda. Journal of Management, 38(4), pp.1084-1114.

Spithoven, A., Clarysse, B. and Knockaert, M., 2011. Building absorptive capacity to organize inbound open innovation in traditional industries. Technovation, 31(1), pp.10-21.

Spithoven, A., Vanhaverbeke, W. and Roijakkers, N., 2013. Open innovation practices in SMEs and large enterprises. Small Business Economics, 41(3), pp.537-562.

Teece, D., 1986. Profiting from technological innovation: Implications for integration, collaboration, licensing and public policy. Research Policv, 15(6), pp.285-305.

Teece, D. J., Pisano, G., \& Shuen, A. 1997. Dynamic capabilities and strategic management. Strategic Management Journal, 18:509-533.

Tsai, K.-H. \& Wang, J.-C., 2007. A longitudinal examination of performance of two ways on innovation in Taiwan: internal R\&D investment and external technology aquisition. International Journal of Technology Management, 39(3-4).

Van de Vrande, V., De Jong, J.P., Vanhaverbeke, W. and De Rochemont, M., 2009. Open innovation in SMEs: Trends, motives and management challenges. Technovation, 29(6), pp.423437.

\section{Page 15 of 18}


West, J. and Bogers, M., 2016. Open innovation: current status and research opportunities. Innovation, pp.1-8.

Weston, C., Gandell, T., Beauchamp, J., McAlpine, L., Wiseman, C. and Beauchamp, C., 2001. Analyzing interview data: The development and evolution of a coding system. Qualitative sociology, 24(3), pp.381-400.

WIPO, 2015. Successful Technology Licensing, IP Assets Management Series, WIPO, Geneva, Switzerland.

Yang, H. and Steensma, H.K., 2014. When do firms rely on their knowledge spillover recipients for guidance in exploring unfamiliar knowledge? Research Policv, 43(9), pp.1496-1507.

\section{Page 16 of 18}

(c) Emerald Publishing Limited

This is a pre-print of a paper and is subject to change before publication. This pre-print is made available with the understanding that it will not be reproduced or stored in a retrieval system without the permission of Emerald Publishing Limited. 
Figures

Figure 1 - Number of Start-Up (1) and Incumbent (0) Licensees Entering Licensing Agreements

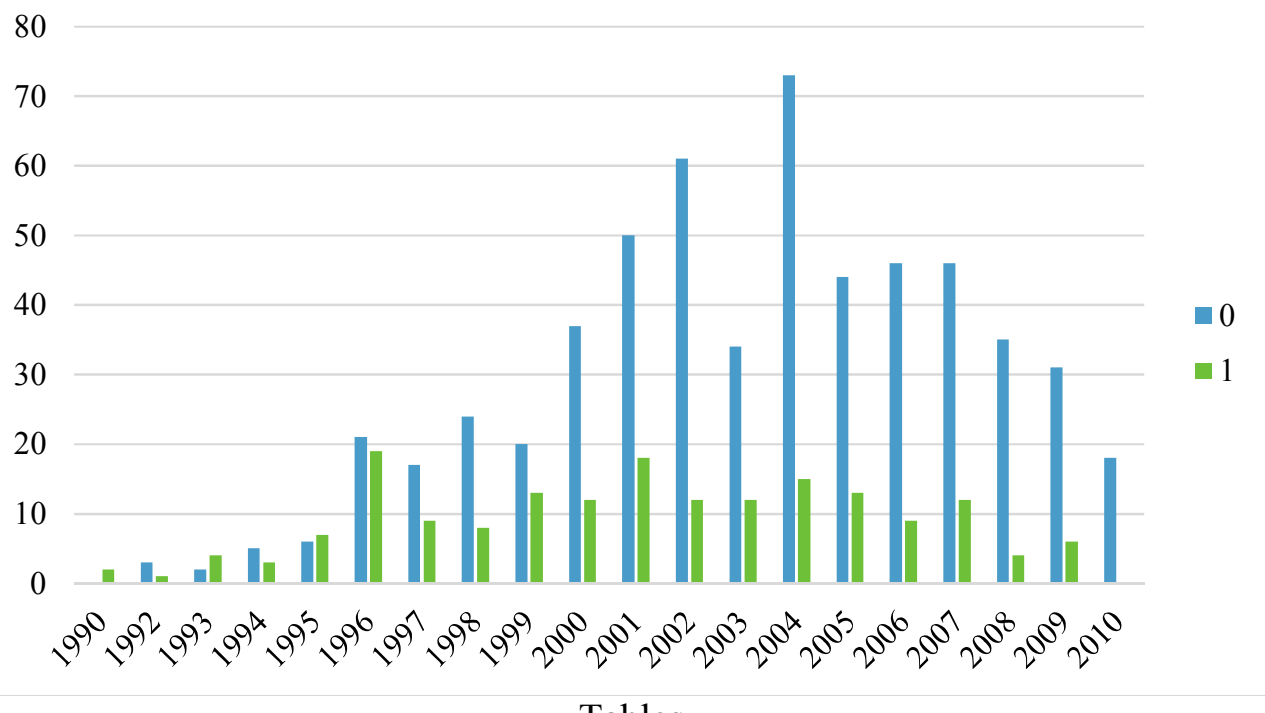

Tables

Table 1 -Licensee Incumbents and Start-Ups per Country (Top 10)

\begin{tabular}{|l|r|r|r|}
\hline Licensee Country & Incumbent & Start-up & Grand Total \\
\hline US & 301 & 95 & 396 \\
\hline DE & 15 & 3 & 18 \\
\hline GB & 13 & 2 & 15 \\
\hline CA & 8 & 3 & 11 \\
\hline JP & 10 & & 10 \\
\hline FR & 4 & 5 & 9 \\
\hline IL & 7 & 1 & 8 \\
\hline CH & 5 & 1 & 6 \\
\hline DK & 4 & & 4 \\
\hline SE & 2 & 1 & 3 \\
\hline
\end{tabular}

Table 2 - Main Technology Classes (Manufacturing and Services) for Licensees

\begin{tabular}{|l|l|r|r|}
\hline $\begin{array}{l}\text { SIC } \\
\text { Code }\end{array}$ & Name & Incumbent & Start-up \\
\hline 2834 & PHARMACEUTICAL PREPARATIONS & 86 & 27 \\
\hline 3841 & SURGICAL \& MEDICAL INSTRUMENTS \& APPARATUS & 28 & 9 \\
\hline 2836 & BIOLOGICAL PRODUCTS, (NO DIAGNOSTIC SUBSTANCES) & 26 & 8 \\
\hline 8731 & SERVICES-COMMERCIAL PHYSICAL \& BIOLOGICAL RESEARCH & 19 & 7 \\
\hline 3845 & ELECTROMEDICAL \& ELECTROTHERAPEUTIC APPARATUS & 15 & 4 \\
\hline 3674 & SEMICONDUCTORS \& RELATED DEVICES & 10 & 8 \\
\hline 7372 & SERVICES-PREPACKAGED SOFTWARE & 14 & 4 \\
\hline 2833 & MEDICINAL CHEMICALS \& BOTANICAL PRODUCTS & 9 & 4 \\
\hline 2835 & IN VITRO \& IN VIVO DIAGNOSTIC SUBSTANCES & 8 & 4 \\
\hline 3826 & LABORATORY ANALYTICAL INSTRUMENTS & 9 & 2 \\
\hline
\end{tabular}

Page 17 of 18

(C) Emerald Publishing Limited

This is a pre-print of a paper and is subject to change before publication. This pre-print is made available with the understanding that it will not be reproduced or stored in a retrieval system without the permission of Emerald Publishing Limited. 
Table 3 - Licensor Types

\begin{tabular}{|l|r|r|r|r|}
\hline \multirow{2}{*}{ Licensor Type } & \multicolumn{4}{|c|}{ Licensee Type } \\
\cline { 2 - 5 } & \multicolumn{2}{|c|}{ Incumbent } & \multicolumn{2}{c|}{ Start-up } \\
& Number & Percentage & Number & \multicolumn{1}{c|}{ Percentage } \\
\hline Private Company & 558 & 67.4 & 270 & 32.6 \\
\hline University & 30 & 65.2 & 16 & 34.8 \\
\hline Research & 6 & 85.7 & 1 & 14.3 \\
\hline Foundation & 3 & 60.0 & 2 & 40.0 \\
\hline Government Entity & 3 & 75.0 & 1 & 25.0 \\
\hline Grand Total & 600 & 67.4 & 290 & 32.6 \\
\hline
\end{tabular}

Table 4 - One-Way Licensing versus Cross-Licensing

\begin{tabular}{|r|r|r|}
\hline & One-Way Licensing & Cross-Licensing \\
\hline Incumbent & $91.97 \%$ & $8.03 \%$ \\
\hline Start-up & $98.60 \%$ & $1.40 \%$ \\
\hline
\end{tabular}

Table 5 - Comparison between Licensor, Licensee and Technology Main SIC Codes

\begin{tabular}{|l|l|l|l|l|l|}
\hline \multirow{2}{*}{} & \multicolumn{5}{|c|}{ Matching SIC Codes } \\
\cline { 2 - 6 } & SOR, SEE, TEC & SEE, TEC & SOR, SEE & SOR, TEC & NONE \\
\hline Incumbent & $1.0 \%$ & $5.1 \%$ & $3.1 \%$ & $3.3 \%$ & $87.4 \%$ \\
\hline Start-up & $0.5 \%$ & $2.8 \%$ & $2.9 \%$ & $1.4 \%$ & $92.4 \%$ \\
\hline
\end{tabular}

Table 6 - Cumulative Average Patent Scope Before and After License Agreement

\begin{tabular}{|l|l|l|}
\hline & At Licensing & After Licensing \\
\hline Incumbent & 13.88 & 5.25 \\
\hline Start-up & 5.29 & 4.73 \\
\hline
\end{tabular}

Table 7 - Change in Main Technology Class before and After License Agreement

\begin{tabular}{|l|l|l|}
\hline & $\begin{array}{l}\text { Same Main Technology } \\
\text { Class }\end{array}$ & $\begin{array}{l}\text { Different Main Technology } \\
\text { Class }\end{array}$ \\
\hline Incumbent & $64.11 \%$ & $35.89 \%$ \\
\hline Start-up & $51.55 \%$ & $48.45 \%$ \\
\hline
\end{tabular}

Table 8 - Cases

\begin{tabular}{|l|r|l|l|}
\hline Firm & Founded & Country & Market \\
\hline A & 2013 & NL & IT \\
\hline B & 2012 & UK & Oil \& Gas \\
\hline C & 2013 & NL & Pharmaceuticals \\
\hline D & 2009 & NL & Energy \\
\hline E & 2011 & NL & Transportation \\
\hline F & 2012 & USA & Electronics \\
\hline G & 2012 & IT & Materials \\
\hline H & 2012 & IT & Energy \\
\hline I & 2013 & IT & Energy \\
\hline
\end{tabular}

Page 18 of 18

(C) Emerald Publishing Limited

This is a pre-print of a paper and is subject to change before publication. This pre-print is made available with the understanding that it will not be reproduced or stored in a retrieval system without the permission of Emerald Publishing Limited. 


\section{Appendix 3 - Sample Representativeness Check}

\section{1) Representativeness Check:}

We compare the original sample of 7676 records to the subsample of 752 agreements on key variables:

- Yearly distribution of agreements. Since Orbis draws from public databases and the stock market, there could be exogenous variables driving the availability of information between the different waves of innovation activity spanning the last decades. To account for this, we tested the representativeness of the sample splitting it into three decades. Overall the sample is representative; we see that as we come to companies participating in more recent licensing activities, the subsample becomes increasingly representative of the overall sample.

- Different sectors. We create dummy variables for the main SIC Codes present in the sample and found that only category 2834 is slightly over-represented in our subsample while all others have no significant differences.

- Service/product license. We also confirmed that the subsample is representative looking at whether product or service technologies are exchanged.

Based on this comparison, we can conclude that the subsample is representative of the overall sample.

Table 11 - Sample Representativeness

\begin{tabular}{|c|c|c|c|c|c|c|}
\hline \multirow[b]{3}{*}{ Variable } & \multicolumn{2}{|c|}{ Individual Samples } & \multicolumn{4}{|c|}{ Difference Between Samples (T-Test) } \\
\hline & \multirow{2}{*}{$\begin{array}{c}\text { Average } \\
\text { Overall Batch } \\
(7676 \\
\text { licenses })\end{array}$} & \multirow{2}{*}{$\begin{array}{c}\text { Average } \\
\text { Subsample } \\
(752 \\
\text { licenses })\end{array}$} & \multirow[b]{2}{*}{ Average } & \multirow[b]{2}{*}{$\begin{array}{l}\text { Std } \\
\text { Dev }\end{array}$} & \multicolumn{2}{|c|}{$95 \%$ Interval } \\
\hline & & & & & $\begin{array}{l}\text { Lower } \\
\text { Bound }\end{array}$ & $\begin{array}{l}\text { Upper } \\
\text { Bound }\end{array}$ \\
\hline Agreement Year 1980-1990 & 1987.26 & 1986.88 & -0.39 & 0.86 & -2.10 & 1.32 \\
\hline Agreement Year 1991-2000 & 1997.33 & 1997.46 & 0.13 & 0.15 & -0.16 & 0.42 \\
\hline Agreement Year 2001-2010 & 2004.65 & 2004.74 & 0.09 & 0.12 & -0.15 & 0.33 \\
\hline SIC Code 2834 & 0.1763 & 0.2407 & 0.0643 & .0156 & 0.0338 & 0.0949 \\
\hline SIC Code 2836 & 0.0667 & 0.0664 & -.0003 & .0100 & -0.0199 & 0.0194 \\
\hline Sic Code 7372 & 0.0657 & 0.0636 & -0.0021 & 0.0099 & -0.0216 & 0.0174 \\
\hline Sic Code 3841 & 0.0607 & 0.0484 & -0.0123 & 0.0095 & -0.0308 & 0.0063 \\
\hline Sic Code 7389 & 0.0474 & 0.0373 & -0.0100 & 0.0084 & -0.0265 & 0.0065 \\
\hline Product (0)/Service (1) & 0.0901 & 0.0982 & 0.0081 & 0.0112 & -0.0139 & 0.0300 \\
\hline
\end{tabular}

\section{2) Additional analysis to exclude that start-ups may be under-represented in our sample due to an over-representation of active companies w.r.t inactive ones in Orbis:}

We checked for differences in active an inactive firms, in 2016, among the incumbent or startup licensees in our subsample. This difference is not statistically significant (T-test $95 \%$ interval is between -0.0525451 and 0.029398). Therefore companies in Orbis do not seem to be biased in favor of active companies, if we compare between start-up and incumbent firms in the subsample.

\begin{tabular}{lrr} 
Status & Incumbent & Startup \\
\hline Active & $91.73 \%$ & $92.89 \%$ \\
Inactive & $8.26 \%$ & $7.11 \%$ \\
\hline Grand Total & $\mathbf{1 0 0 . 0 0 \%}$ & $\mathbf{1 0 0 . 0 0 \%}$
\end{tabular}

